\title{
Local Wisdom Preservation in Inter-Ethnic Weddings in Cimahi City's Batak Karo Community
}

\author{
Lili Halimah', Heni Heryani, Eva Enzelia Barus \\ Prodi Pendidikan Pancasila dan Kewarganegaraan STKIP Pasundan, Jawa Barat, Indonesia \\ 1lili.halimah@gmail.com
}

\begin{abstract}
North Sumatra province has a variety of unique cultures, one of which is marriage tradition and wedding ceremony. Marriages-containing noble values and norms of the purpose of life-are legally bound in traditional wedding ceremonies so the marriage will be safe. In Batak Karo tribe, one of the tribes in North Sumatra, the ideal marriage is the one that follows the rimpal tradition, which means that a man will be recommended to marry the daughter of his mother's brother. In its development, inter-ethnic marriages provide a solution to overcome the problems of unideal marriage, particularly when far from home. This article describes the condition when the ideal marriage is not fulfilled. The study used qualitative approach in the Karo Persadaan community in Cimahi City, West Java, involving the role of religious and traditional leaders. The results of the study show that inter-ethnic weddings in the Batak Karo community are allowed but with complete customary procedures as performed in ideal wedding ceremonies to preserve their local wisdom and prevent the Batak Karo identity from being extinct overseas.
\end{abstract}

Keywords: local wisdom, traditional ceremony, inter-ethnic marriage, Batak Karo tribe

\begin{abstract}
ABSTRAK
Sumatera Utara memiliki beragam budaya yang unik, salah satunya adalah perkawinan. Perkawinan mengandung nilai luhur dan norma dari tujuan hidup berumah tangga dan dilakukan melalui upacara adat, agar perkawinan itu selamat. Perkawinan ideal dalam Suku Batak Karo adalah pernikahan yang mengikuti tradisi rimpal, yakni dari pihak laki-laki akan direkomendasikan untuk menikahi anak perempuan saudara laki-laki ibunya. Terjadinya perkawinan campuran antar-etnis dalam perkembangannya memberikan jalan keluar untuk mengatasi masalah perkawinan yang tidak ideal. Artikel ini berusaha menggambarkan jika perkawinan ideal tidak terpenuhi. Pendekatan yang dipilih dengan menggunakan pendekatan kualitatif dan dilakukan pada komunitas Persadaan Karo di Kota Cimahi, serta melibatkan peran tokoh agama, dan tokoh adat. Hasil penelitian adalah perkawinan campuran antaretnis pada Suku Batak Karo dapat dilakukan namun harus menyelesaikan tata cara adat yang seharusnya dilakukan pada perkawinan ideal, sebuah proteksi kearifan lokal agar jati diri bagi Suku Batak Karo tidak punah sekalipun di perantauan.
\end{abstract}

Kata kunci: kearifan lokal, upacara adat, perkawinan antar-etnis, suku Batak Karo

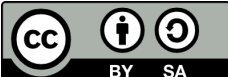

This work is licensed under the Creative Commons Attribution-ShareAlike 4.0 International License. (02020 by the author(s).

\section{INTRODUCTION}

Indonesia consists of various ethnic groups with each of their unique cultural styles. Society as the supporter of culture is not immune from changes. Changes always happen because of the various needs of the increasingly complex community 
due to the natural and social situations. Changes that occur in a community are usually preceded by certain event, both from within and outside of the community. Roads, traces and practices of culture, traditions, customs and informal law are still inherent, integrated and existed in the practice of modern Indonesian society (Candraningrum, 2015).

Indonesia is rich in cultural diversity because Indonesia consists of various unique and distinguished ethnic groups that enrich the Indonesian culture (Prayogi \& Danial, 2016). The ethnic cultures can be seen in human behavior in daily life and in their relations with others that will lead to interactions (Soekanto, 1990). Those many ethnic groups composed of or formed by families. The families are parts of a society which will form a nation. Everything that influences life and interaction between families will affect the socio-culture of the nation.

Marriage is a process of making a new family and an "interaction" among families. Marriage is also one of the many human life cycles. One of the elements of traditional culture is the traditional wedding ceremony which establishes and regulates a very important form of relationship between two people of opposite sex. For Batak people marriage contains noble values and norms for the purpose of the family life. This can be seen in the symbols and manners in a wedding ceremony. Performing a traditional wedding ceremony is intended to protect the marriage (Pelawi \& Kartikasari, 1998, p. 86).

North Sumatra is one of the provinces in Indonesia that has a rich cultural diversity in the customs of wedding, death and birth ceremonies, inheritance system, traditional arts, and local languages (Bayosuti, 2015). Batak Karo is one of the tribes of the Batak ethnic group, which is predominant in North Sumatra province. For the Batak Karo tribe, marriage is a physical and spiritual happiness to get offsprings and maintain the kinship so that the inheritance rights go directly to the sons and get recognition from relatives of the community where the wedding ceremony took place (Sinuhaji, 2013, pp. 114-122). The ideal marriage in Batak Karo tribe is a marriage which follows the tradition of rimpal, a person designated to be someone's future spouse. A Batak Karo man is highly recommended to marry the daughter of his mother's brother. This means that from the beginning, a man would be recommended to marry his impal.

A marriage that is considered ideal in Batak Karo community is the one between a pair of rimpal, which means between a man and the daughter of his mother's brother. Therefore, a Batak Karo man is not allowed to marry a woman who has the same surname (marga) nor the daughter of his father's sister. If the man cannot or do not want to marry his rimpal, he can marry another woman whose surname (beru) is the same with his mother (nande). This marriage is thus known as singumban nande (singumban = successor) (Pinem, Sinaga, \& Yustia., 2019). For the Batak Karo community, the marriage system and kinship will influence the continuity of their customs and traditions. Batak Karo people maintain marriage in a tradition that has been determined for generations. In Batak Karo tribe, a man or a woman is obliged to marry his impal, called the ideal partner. Culturally, every Batak person advises his/her descendants to marry fellow Batak people to preserve the values to become the principles of Batak community, including the norms that 
regulate such marriage tradition (Sondang, 2016).

An inter-ethnic wedding will force the families to choose between customary rule and/or religious rule to be implemented in the wedding ceremony. However, in its development, local customary rule provides a solution to overcome this problem so that inter-ethnic weddings can be held (Sembiring \& dkk, 2016, pp. 35-36). Batak Karo people do not prohibit inter-ethnic weddings and marriages. Now Batak Karo tribe conducts inter-ethnic weddings with the terms and conditions suitable with their custom, for example, it should not violate traditions that has been passed down for generations. Moreover, inter-ethnic weddings must follow the procedure of Batak Karo ideal wedding ceremonies and must first appoint a surname for the nonBatak brides/grooms so that they are not referred to as people who do not have a custom (Manalu, 2015).

Based on the customary rule, inter-ethnic marriage means a marriage between a man and a woman from different ethnic groups, both within the unity of their indigenous groups and of different national communities. Koentjaraningrat (Silalahi, 2016) defines mixed marriage as a marriage resulting from acculturation, which occurs when a group of people with their culture is confronted with different foreign cultural elements, therefore the foreign cultural elements can be accepted gradually and processed into their culture without eliminating their own cultural personality.

Inter-ethnic marriages are found among Batak Karo Persadaan community in Cimahi city, West Java, as shown in Table 1.

Table 1. Families in inter-ethnic marriages among Persadaan Community

\begin{tabular}{lll}
\hline No & Non-Batak Spouses' ethnic groups & Number of families \\
\hline 1 & Javanese & 16 \\
\hline 2 & Sundanese & 14 \\
\hline 3 & Dayak & 2 \\
\hline
\end{tabular}

Source: (Bethel, 2019)

Based on the table, the data shows that Batak Karo people mostly have interethnic marriages with people from the Javanese, Sundanese and Dayak ethnic groups. Mixed marriage with the Javanese people are the most common because the Javanese families do not play a significant role in influencing the selection of future spouses (Alesandra, 2014, p. 30). Based on data and facts as well as preliminary observations, it is found that the Batak Karo community does not prohibit interethnic marriages. This research explores the inter-ethnic wedding ceremonies in Cimahi City's Batak Karo community as a preservation of local wisdom overseas. This article explains the motivations, customary procedures, payment of bride-price, values, impacts, and division of inheritance in inter-ethnic weddings and marriages.

\section{RESEARCH METHOD}

The study was conducted in Karo Persadaan community in Cimahi city, West Java. Religious leaders, traditional leaders, and Batak Karo families in inter-ethnic marriages are the source of data in this research. Qualitative approach was chosen to analyse and examine the condition of natural objects, where researchers are the key 
to data collection techniques through observation, interviews, and documentation. Data analysis was inductive to understand meaning, construct phenomena and find hypotheses (Sugiyono, 2017, p. 57). Qualitative research seeks to understand a given research problem or topic from the perspectives of the local population it involves. Qualitative research is especially effective in obtaining culturally specific information about the values, opinions, behaviors, and social contexts of certain populations (Readings, 2005).

Qualitative research is "a form of systematic empirical inquiry into meaning". Systematic means "planned, ordered and public", following rules agreed upon by members of the qualitative research community. Empirical means that this type of inquiry is grounded in the world of experience (Goethals, Sorenson, \& J., 2004). Through qualitative research we can explore a wide array of dimensions of the social world, including the texture and weave of everyday life, the understandings, experiences and imaginings of our research participants, the ways that social processes, institutions, discourses or relationships work, and the significance of the meanings that they generate (Mason, 2002).

In qualitative research, the main instrument is the researcher(s). Then the focus of the study will be clear, it will be assisted by the completion of data and its comparison with the data found through observations and interviews. Researchers gather the data in the field directly, analyse it, and make conclusions.

Qualitative research can be accounted for if its already tested for the validity or the credibility of the data (Sugiyono, 2017). This research data was analysed using an interactive model that refers to the one by Miles and Huberman which includes data reduction, data presentation, and conclusions (Miles \& A.M., 1992). The interview guidelines is described in the table below.

Table 2. Interview Guidelines

\begin{tabular}{|c|c|c|c|}
\hline No & $\begin{array}{c}\text { Formulation of } \\
\text { the problem }\end{array}$ & Questions & Data sources \\
\hline 1. & $\begin{array}{l}\text { How are the } \\
\text { traditional inter- } \\
\text { ethnic weddings } \\
\text { of Batak Karo } \\
\text { people held? }\end{array}$ & $\begin{array}{l}\text { 1.1. Is it allowed according to the } \\
\text { tradition? } \\
\text { 1.2. What are the motivations? } \\
\text { 1.3. What are the procedures and how } \\
\text { the bride-price (uang jujur) is paid? } \\
\text { 1.4. What are the values? } \\
\text { 1.5. What are the impacts? } \\
\text { 1.6. How is the inheritance divided? }\end{array}$ & $\begin{array}{l}\text { 1. Traditional } \\
\text { leaders } \\
\text { 2. Church leaders } \\
\text { 3. Families in } \\
\text { ideal marriages } \\
\text { 4. Families in } \\
\text { inter-ethnic } \\
\text { marriages }\end{array}$ \\
\hline 2 & $\begin{array}{l}\text { What efforts are } \\
\text { done by the } \\
\text { figures who play } \\
\text { a role in } \\
\text { maintaining } \\
\text { local wisdom in } \\
\text { inter-ethnic } \\
\text { weddings and }\end{array}$ & $\begin{array}{l}\text { 2.1 Do the Batak Karo people in } \\
\text { Cimahi still hold cultural values } \\
\text { strictly? } \\
\text { 2.2 Are the cultural values in inter- } \\
\text { ethnic weddings in Cimahi City still } \\
\text { maintained? } \\
2.3 \text { How does the Batak Karo tribe } \\
\text { maintain the local wisdom values of }\end{array}$ & \\
\hline
\end{tabular}




\begin{tabular}{ll}
\hline marriages? & inter-ethnic weddings? \\
& 2.4 How do Batak Karo people \\
& maintain local wisdom in inter-ethnic \\
& weddings? \\
\hline
\end{tabular}

\section{RESULTS AND DISCUSSION}

The research was conducted in the Indonesian Bethel Church in Cimahi City, the Persadaan Karo Community. The community was pioneered by Mrs. Ruth Elfrida Purba in January 2016, with the vision to establish the Batak Karo worship community. The community's mission is to invite every congregation member and hold Batak Karo related events with the aim of re-establishing the kinship of Batak Karo congregation overseas. The number of members of this community is around 200 people. The organizational structure can be seen in the table below.

Table 3. Persadaan Karo Community in Cimahi City

\begin{tabular}{|c|c|c|}
\hline No & Members of Persadaan Karo Community & Position \\
\hline 1 & Lemba Ginting & Chairman \\
\hline 2 & Friska Tarigan & Secretary \\
\hline 3 & Novi Tarigan & Treasurer \\
\hline 4 & Tenang Sembiring & Member \\
\hline 5 & David Purba & Member \\
\hline 6 & Johanes Sembiring & Member \\
\hline 7 & Jakub Barus & Member \\
\hline 8 & Mulia Ginting & Member \\
\hline 9 & Dalam Ginting & Member \\
\hline 10 & Rupenta sitepu & Member \\
\hline 11 & Josua Ginting & Member \\
\hline 12 & Cindy PasarRibu & Member \\
\hline 13 & Rico Sitepu & Member \\
\hline 14 & Nurlina Sebayang & Member \\
\hline 15 & Jaharia Ginting & Member \\
\hline 16 & Terikut Ginting & Member \\
\hline 17 & Alnof Tarigan & Member \\
\hline 18 & Ester Turnip & Member \\
\hline 19 & Saulus Bukit & Member \\
\hline 20 & Anton Milala & Member \\
\hline 21 & Herry Tarigan & Member \\
\hline 22 & Susan Sebayang & Member \\
\hline 23 & Ormade & Member \\
\hline 24 & Debora & Member \\
\hline 25 & Heizer Purba & Member \\
\hline 26 & Novi Ginting & Member \\
\hline 27 & Tamhun Tarigan & Member \\
\hline 28 & Pianika Pinem & Member \\
\hline
\end{tabular}

Source: (Karo, 2019) 
For the interviews, we met with Mr. J. Barus (JB), Ms. E. Ginting (EG), Mr. M. Ginting (MG), Mrs. F. Tarigan (FT), Mr. D. Purba (DP), Mrs. Ruth Elfrida Purba (REP) as religious leaders and founders of Karo Persadaan community as well as Mr. Yusuf Sembiring (YS) as a Batak Karo traditional figure in Cimahi City. Those respondents were interviewed for their knowledge about kinship system, motivation, customary procedures, bride-price payment, values, impacts, and inheritance system in inter-ethnic wedding ceremonies and marriages, as seen in the following table.

\section{Table 3: Resume of Interviews}

The kinship The kinship system in general has begun to be forgotten by the Batak system Karo people who engage in inter-ethnic marriages particularly those who were born and raised overseas, unlike the people who are in ideal marriage.

Motivation The people in inter-ethnic marriages believe that it is the Almighty's for mixed will to match a man/woman with anyone his/her heart desires. marriages Another factor is the condition overseas where they interact a lot with people from other ethnic groups and tribes even though they still implement the customary provisions.

Traditional The non-Batak potential brides/grooms are adopted to a Karo family custom for by bestowing them a surname according to the Karo custom. They can inter-ethnic choose another surname, but they should still implement the Karo wedding wedding procedures. By doing this, they are considered to belong to the Karo people. The principle is to adopt people from the outside to be the children of the family, to be a part of the community.

Bride-price The bride-price (honest money/uang jujur/uang tukur) in Batak Karo (uang jujur) inter-ethnic weddings are different from the ones in ideal weddings. If in an ideal wedding the amount of bride-price uses the standard based on certain regional rules, a bride-price of inter-ethnic wedding depends on the deliberation procedure. However, there will usually be only a slight difference.

The value The values of learning to respect each other between two people from different cultural background. There is also the value of acknowledging the previously unknown cultural values in terms of psychology and customs.

The impact There must be a significant impact of mixed marriages for the pairs, but they can handle the differences, so it will not affect the domestic life. However, the children are not familiar with the customs and descendants of their parents because of the influence of other customs and different cultures even though the parents have minimized the difference as much as possible.

The The division of inheritance in inter-ethnic marriages follow the division of national custom which is fair and equitable. It means the inheritance inheritance will be given to a son or divided equally among the sons, while daughters do not get any share because they are expected to be 
married and financed by their husbands. However, a brother(s) can willingly give a little share to the sisters. This means the daughters get inheritance through her/their brother(s).

Neither Batak Karo people nor the churches prohibit inter-ethnic marriages, as long as the pairs are of the same faith. Meeting a soulmate, even though he/she comes from other ethnic groups or tribes, is believed to be a destiny. Some of the motivations to engage in inter-ethnic marriages are modernization, both in education and technology. Leaving their hometown and living overseas also have broadened someone's horizons. Living in a foreign land makes them socialize with people other than Batak Karo, and in case of love bonds the cultural differences are no longer obstacles.

The inter-ethnic marriages in Batak Karo community represents Ferawati's statement (2014) that an inter-ethnic marriage happens between two people who have different cultural backgrounds that the couple has each cultural values, customs, and habits, but united in marriage ties. Furthermore, Koentjaranigrat states that a mixed marriage happens between a man and a woman who have different cultures and come from different ethnic groups. Naturally, an inter-ethnic marriage happens because of love. Others are motivated to engage in inter-ethnic marriages due to the practical reason to avoid their customs, to improve the social status, to have an adventure in experiencing something different, to learn something new, and other idealistic reasons (Silalahi, 2016). Sondang (2016) explains that the progress of modernization and the development of science make all kinds of human thought become more advanced. Over time, the phenomenon of modernization makes most cultural traditions gradually loosen.

It can be concluded that mixed marriages are the marriages that happen between two different cultures and have been united in marriage ties. In Batak ethnic group, particularly the Batak Karo tribe, it is not prohibited to engage in mixed marriage. The reason someone engages in a mixed marriage is love, while over time the advancement of knowledge and modernization make certain traditions loosen. The Batak Karo community, in organizing wedding cceremonies, has been applying terms and conditions based on their custom, one of which is not violating traditions that has been passed down for generations. Therefore, inter-ethnic weddings must follow the procedures applied in ideal wedding ceremonies and must first appoint a surname for the non-Batak brides/grooms so that they will not be considered "without custom" (Manalu, 2015).

Interviews with the traditional leaders reveals that the procedure that must be implemented in an inter-ethnic wedding between a Batak Karo and a non-Batak Karo person is to first bestow a surname (marga), or hold a procession of bestowing a surname to the latter. For a non-Batak Karo bride, the surname (beru) bestowed is the same with the groom's mother's, which makes her officially a member of Batak Karo community. As Fitriatmoko (2017) wrote, it is a general practice in Batak ethnic group to adopt the non-Batak bride/groom as a Batak person (by bestowing a Batak surname to him/her).

The surname bestowal procedure is a ceremony that must be performed 
before the wedding. This procedure is attended by kamlimbubu and those who are most involved in rakut sitelu, meaning the significant members of the extended family. After the surname bestowal ceremony, the non-Batak person is officially a part of the Batak community. However, this procedure will not eliminate the position of the original parents because they will still be involved with adoptive parents.

The bestowal procedure is followed by several steps called the mbamba belo selembar, nganting manuk, and puncak adat or kerja adat. The bride and groom are also allowed to hold other ceremonies based on traditions or customs from the other culture. The most important thing is to keep implementing the mandatory customs in the Batak Karo tribe, unless it will be called terhutang adat (literally means owing the traditions), which means having forgotten the traditions, as also the impact in an ideal wedding.

Another important element in a wedding ceremony is the bride-price. The amount of bride-price (uang tukur) in inter-ethnic weddings is different from the ones in ideal weddings. Even so, the difference is not too significant compared to the ideal wedding. It is the role of runggun, the important family members, to deliberate the bride-price amount during the nganting manuk procedure, a step to plan the wedding ceremony. A man in an inter-ethnic marriage said that he gave a 10-gram of gold for bride-price. As Simbolon (2013) revealed, marriages in Batak community were known as honest marriages, therefore the bride-price-a sum of money given by the groom to the family of the bride-is called uang jujur (literally means honest money) or uang tukur. In previous times, the uang jujur bride-price was given in the form of objects. Over time, it is given as a sum of money. The size and amount of the bride-price depend on the agreement between the two parties; there is no specific benchmark regarding the amount of money. Uang jujur (bride-price) and dowry are two different things. Uang jujur bride-price is a customary obligation that the groom must give to the bride's family, while dowry is the groom's obligation to give to the bride based on religious rule. The bride-price is also called uang tukur, as it is not meant as a purchase, but a payment.

There are values embedded in every ceremony and tradition. The values in inter-ethnic marriages are customary values, understanding and appreciation values, psychological values, and the unification of values from both cultures. Setiadi (2007) explains that values have two contexts. In the first context, values are viewed as objective, which can distinguish between the good and the bad, the right and the wrong. In the second, values are subjective, which means that values depend on how someone judges them. Values are also everything that have been inherent in human beings which must be maintained and carried out in love, understandings, morals, and ethics. The value in inter-ethnic marriages is subjective, namely how a person views the mixed marriages, as well as the ones that have been inherent in him/her.

The mixed marriages also have unique effects not experienced in ideal marriages. The mixed marriages impact the couples and the relatives on their daily habits. There should be a mutual understanding between the couple and their relatives to be able to put themselves in the right position because of those cultural differences. The positive effect is that the couple of an inter-ethnic marriage will give 
a new insight to the character and culture of each other. According to Atwater in Hidayati (2017), marital adjustment is a couple's process to learn to adjust to each other, communicate, deal with conflict, and adjust to the changes over the length of their marriage. Therefore, a marriage between two people from different ethnic groups requires the ability to adjust well to achieve a successful marriage.

The children in inter-ethnic marriages will follow the kinship system of one of their parents, as well as the way they behave and talk. Some children cannot understand well both parent's cultures. Saputri (2017) argues that the impact of inter-ethnic marriages on children is the cultural dominance that is known by children of inter-ethnic marriages. First, regarding the kinship system, that it is created because of heredity. Second, regarding the way of speaking, accent, as well as culture, including art and dance. The same was expressed by Fitriatmoko (2017), who explained that mixed marriages will have various impacts, including the implementation of culture, hereditary, kinship, and inheritance system. Children are not used to absorb the values of their parents' culture, but rather recognize the local culture where they live. Children in mixed marriages in Batak Karo community will follow the kinship and hereditary system from their father. Children of mixed marriages are only able to master one local language and one culture from both cultures of their parents.

Marriage system also rules about inheritance. Inter-ethnic couples in the Batak Karo community said that they decided to divide the inheritance according to the national custom instead of the Batak Karo system. Meanwhile, traditional leaders explained that the division of inheritance in both ideal and mixed marriages are the same; it is based on the Batak Karo hereditary system, which means that sons get full inheritance from both parents. If a woman from Batak Karo tribe marries someone from another tribe or ethnic group, her children will follow the hereditary system of her father.

As Sembiring stated (2016), the Batak Karo hereditary system has been implemented since ancient times, but the division of inheritance has changed over time. In the past, the inheritance was divided according to the father's lineage, which means only a son was entitled to the inheritance. If there were more than one son, the inheritance will be shared evenly between them, while the daughter(s) were not entitled to receive it. She/They would only get a share if it is given by her/their brother(s). If a couple did not have a son, the inheritance would go to the husband's brother. Due to the modernization and the difficulty to implement this system nowadays - some inflict disputes and even legal battle-the patrilineal hereditary system has shifted to become the parental hereditary system.

In the inter-ethnic marriages in Batak Karo tribe, the hereditary system is the same as the one in ideal marriages. The difference is that when a woman from Batak Karo tribe marry someone from another tribe, their children will follow the father's hreditary system. However, interviews in this research reveal that inter-ethnic couples decide to divide their inheritance according to the national custom, which gives equal rights between sons and daughters.

Currently most Batak Karo people in Cimahi City do not perform traditional wedding ceremonies, both in ideal and mixed marriages. The reasons are the cost, 
time, and the complex procedures. Gradual changes over time leads to the fade of these customs. Traditional figures revealed that there are always efforts to maintain the customs and traditions in ideal and inter-ethnic weddings in Cimahi City. They usually talk to families and prospective brides and grooms, offering help in implementing the traditions and begging to maintain the local wisdom although they live overseas. This shows the importance of tradition and the impact it will have in the future.

Lubis in Sukmayadi (2016) defines local wisdom or traditional wisdom as everything that is rooted in the past which has become a reference for the future life order. Furthermore Pitopang (2014) explains that local wisdom is a cultural identity of an ethnic group, so that it can absorb the character and personality of the ethnic group. Maintaining local wisdom is not easy, as globalization has unwittingly become a part of life, thus the tendency to loosen traditional values. Garna in Wijakarno (2013) argues that traditional wisdom is a system in a traditional society to protect the environment and there are several belief systems, cultural values, and ways of thinking. Supsiolani (2013) states that local wisdom is an aspect that includes value systems, procedures, special provisions, and advices. Maintaining the Batak Karo marriage traditions and traditional wedding ceremonies is a collective task of Batak Karo community and accommodated by Article 32 (1) of the UUD 1945 Constitution that says "the State shall advance Indonesia's national culture among the civilizations of the world by guaranteeing the freedom of the people to maintain and develop cultural values."

\section{CONCLUSION}

Batak Karo people acknowledge an ideal marriage between a man and the daughter of his mother's brother (impal) because it renewed the relations between the relatives of the bride/mother or Kalimbubu (giver of a daughter) and relatives of the groom/father or Anak Beru (receiver of a daughter) which has happened before. However, social changes over time make some Batak Karo people marry the ones other than their impal. Batak Karo people recognize several steps of a wedding ceremony that must be performed and implemented before, during, and after the wedding. Batak Karo people do not prohibit inter-ethnic marriages. The motivations to have inter-ethnic marriages are love and practical reason to avoid the customs. Moreover, social changes, progress, and modernization make cultural traditions loosen gradually. Many Batak Karo people in Cimahi City do not implement traditional wedding ceremonies, including the fellow Batak Karo weddings and inter-ethnic weddings. The reasons for not doing the ceremony are the cost, time, and the complexity. Therefore, one way to maintain the local wisdom in Batak Karo community is by completing the obligatory customs to become the identity of Batak Karo tribe overseas.

\section{REFERENCES}

Agustinus. (2013). Kearifan Lokal Budaya Ain Ni Ain Masyarakat Kei sebagai Sumber Belajar Sejarah Untuk Memperkokoh Kohesi Sosial Siswa. (p. 40). Bandung: Universitas Pendidikan Indonesia. 
Ahmad Yunus, d. (1994). Makna Pemakaian Rebu dalam Kehidupan Kekerabatan Orang Batak Karo. Jakarta: Dapertemen Pendidikan dan Kebudayaan (tidak untuk diperdagangkan).

Alesandra, L. M. (2014). Perbedaan Kepuasan Perkawinan Suami Istri Ditinjau dari Etnis Cina dan Jawa. Universitas Surabaya (p. 30). Surabaya: Tidak di Terbitkan.

Bayosuti. (2015, January 09). Kaskus. Retrieved Oktober 20, 2018, from Etnis asli di Sumatra

Utara: https:/ / www.kaskus.co.id/thread/54afeca31a997556398b4578/8-etnis-aslidi-sumatera-utara/

Bethel, G. (2019, September 10). Anggota Komunitas Persadaan Karo yang melakukan Perkawinan Campuran. (Peneliti, Interviewer)

Candraningrum, D. (2015). Catatan Jurnal Perempuan: Budaya, Tradisi, Adat. Jurnal Perempuan Untuk Pencerahan dan Kesetaraan ISSN 1410-153X Vol 20 No 1 Februari 2015, iii.

Elly Setiadi, d. (2007). Ilmu Sosial dan Budaya Dasar. Bandung: Kencana Prenanda Media Group.

Ferawati, T. (2014). Suatu Perkawinan antara Etnis Jawa dan Etnis Gorontalo. Jurnal Mahasiswa, 12(3), 1-10.

Fitriatmoko, S. T. (2017). Praktik Perkawinan Cmapuran Antar Masyarakat Adat di Kota Batam dan Akibat Hukumya. Diponegoro Law Journal, 6(2), 1-12.

Goethals, G., Sorenson, G., \& J., M. (2004). Encyclopedia of Leadership. London, Thousand Oaks CA, New Delhi: Copyright (C) 2004 SAGE Publications.

Hidayati, S. (2017, Maret). Penyesuaian Budaya dalam Perkawinan. Journal of Multicultural Studies in Guidance and Counseling, 1(1), 83-98.

Karo, P. (2019, September 19). Data Komunitas Persadaan Karo. (Peneliti, Interviewer)

Koentjaraningrat. (2009). Pengantar Ilmu Antropologi. Jakarta: Penerbit Rineka Cipta.

Manalu, M. T. (2015). Kebertahanan Perkawinan Ideal Menurut Hukum Batak Karo di Kelurahan Kuala Bekala Padang Bulan Medan. Skripsi (p. 23). Bali: Udayana.

Mason, J. (2002). Qualitative Researching Second Edition. New Delhi: SAGE Publications London - Thousand Oaks.

Miles, M., \& A.M., H. (1992). Analisis Data Kualitatif. Terjemahan oleh Tjetjep Rohendi Rohidi. Jakarta: UPI.

Nadjaneruda. (2014, July 7). Kearifan Lokal. Retrieved 11 12, 2018, from https:/ / nadjaneruda.wordpress.com/2014/07/07/kearifan-lokal/

Nugrahani, F. (2014). Metode Penelitian Kualitatif dalam Penelitian Pendidikan Bahasa. Surakarta: Pilar Media Yogyakarta.

Pelawi, K. S., \& Kartikasari, T. (1998). Pandangan Generasi Muda Terhadap Upacara Perkawinan Adat di Kota Medan. Jakarta: Proyek Pengkajian dan Pembinaan Nilai-Nilai Budaya Pusat Direktori Sejarah dan Nilai Tradisional Direktorat Jenderal Kebudayaan Departemen Pendidikan dan KebudayaanCV. Pialamas Permai. 
Pelawi, S. K., Tatiek, K., \& Pertiwi, W. (1998). Pandangan Generasi Muda Terhadap Upacara Perkawinan Adat di Kota Medan. Jakarta Edisi 11998: Proyek Pengkajian dan Pembinaan Nilasi- Nilai Budaya Pusat Direktorat Sejarah dan Nilai Tradisional Direktorat Jenderak Kebudayaan Departemen Pendidikan dan Kebudayaan CV Piala Mas.

Pinem, J. R., Sinaga, R. M., \& Yustia., E. S. (2019). Tradisi Rimpal di kalangan Generasi Muda suku Batak Karo di Kecamatan Tanjung Senang Kota Bandar Lampung. Jurnal Pendidikan dan Penelitian Sejarah (Pesagi) Vol 7 No 3 Tahun 2019.

Pitopang, A. (2014, January 12). Kearifan Lokal untuk Indonesia. Retrieved 11 12, 2018, from kompas: https:/ / www.kompasiana.com/akbarisation

Prabowo, A. (2013). Analisis Pemanfaatan Buku Eletronik oleh Pemustakaan di Perpusatakaan SMA Negeri 1 Semarang. Jurnal Ilmu Perpustakaan, 2(2), 1-9.

Prayogi, R., \& Danial, E. (2016). Pergeseran Nilai-Nilai Budaya pada Suku Bonai Sebaga Civic Culture di Kecamatan Bonai Derusalam Kabupaten Rokan Hulu Provinsi Riau. Humanika, 23(1), 61.

Readings, S. (2005). Qualitative Research Methods: A Data Collector's Field Guide Module 1 Qualitative Research Methods Overview 2005 FAMILY HEALTH INTERNATIONAL S Readings. USAID: FAMILY HEALTH INTERNATIONAL under the terms of Cooperative Agreement No. CCP-A-00-95-00022-02. ISBN: 0-939704-98-

6https:/ / course.ccs.neu.edu/is4800sp12/resources/qualmethods.pdf.

Saputri, F. (2017). Dominasi Budaya pada Perkawina Campuran Antar Etnis. (pp. 19). Pontianak: Untan Pontianak (tidak untuk diterbitkan).

Sari, D. P. (2016). Kajian Perkawinan Endogami di Kelurahan Condong. Skripsi. Yogyakarta: Universitas Negeri Yogyakarta (Tidak di Terbitkan).

Sembiring, A. F. (2005). Perkawinan Semarga dalam Klan Sembiring pada Masyarakat Karo di Kelurahan Tiga Binanga Kecamatan Tiga Binanga, Kabupaten Karo. Semarang: Program Pascasarjana Universitas Dipenogoro.

Sembiring, V. A., \& dkk. (2016). Perkembangan Pembagian Pewaris Masyarakat Batak Karo di Kabupaten Sumatra Utara. Diponogoro Law Jurnal, 5(3), 1-14.

Silalahi, L. (2016). Proses Akultrasi antar Etnis Jawa dan Etnis Batak di Desa Malosor, Kecamatan Dolok Masahul, Kabupaten Serdang Bedagai, Provinsi Sumatra Utara. Riau: Universitas Riau (Tidak di Terbitkan).

Simbolon, A. (2013). Pemberian Jujur dalam Perkawinan Adat Mayarakat Batak (Batak Toba, Batak Simalungun, dan Batak Karo) di Kecamatan Galang Kabupaten Deli Serdang. (p. 6). Yogyakarta: Universitas Gdjah Mada Yogyakarta (tidak untuk diterbitkan).

Sinuhaji, M. (2013). Pelestarian Adat dalam Upacara Perkawinan Masyarakat Batak Karo sebagai Atraksi Wisata dalam menunjang Kepariwisataan di kabupaten daerah tingkat II Karo. Jurnal Geografi Vol 5 No 1 tahun 2013, 114-122.

Soekanto, S. (1990). Sosiologi Suatu Pengantar. Jakarta: PT Raja Grafindo Persada.

Sondang, F. (2016). Kontruksi Sosial Hukum Adat Pernikahan Masyarakat Batak. Surabaya: Universitas AirLangga (Tidak di Terbitkan). 
Sugiyarto. (2014). Menyimak (Kembali) Integrasi Budaya di Tanah Batak Toba. Jurnal Ilmiah Kajian Antropologi, 35.

Sugiyono. (2017). Metode Penelitian Kualitatif. Bandung: Alfabeta Bandung.

Sukmayadi, T. (2016). Kajian tentang Karakter Berbasis Nilai-Nilai Kearifan Lokal pada Masyarakat Adat Kampung Kuta Kecamatan Tambaksari Kabupaten Ciamis. Jurnal Civic, 13(1), 96-112.

Supardan, D. (2015). Pengantar Ilmu Sosial. Jakarta: PT Bumi Aksara.

Supsiloani. (2013, Desember). Dukungan Kearifan Lokal dalam Memicu Perkembangan Kota. Jurnal IPS, 5(2), 9-19.

Syan, A. (2013, April 17). Kearifan Lokal Sebagai Aset Budaya Bangsa Dan Implementasinya Dalam Kehidupan Bermasyarakat. Retrieved 11 12, 2018, from http://staff.unila.ac.id/abdulsyani/2013/04/17/kearifan-lokal-sebagai-asetbudaya-bangsa-dan-implementasinya-dalam-kehidupan-masyarakat/

Veeger. (1989). Ilmu Budaya Dasar. Jakarta: PT Prenhallindo.

Wijakarno, B. (2013, Oktober). Pewarisan Nilai-Nilai Kearifan Tradisonal dalam Masyarakat Adat. Jurnal Pendidikan Geografi, 13(2), 60-72.

Yulia. (2016). Buku Ajaran Hukum Adat. Sulewesi: Unimal Press. 